\title{
ON A METHODOLOGICAL APPROACH TO THE PROBLEM OF QUANTITATIVE RISK ASSESSMENT FOR SPACE HARDWARE DEVELOPMENT PROJECTS (PART I)
}

\author{
Institute of Technical Mechanics \\ of the National Academy of Sciences of Ukraine and the State Space Agency of Ukraine \\ 15 Leshko-Popel St., Dnipro 49005, Ukraine;; e-mail: pkorol@ukr.net
}

The aim of this work is to construct a theoretical basis for the development of methods, algorithms, and software for quantitative assessment of new space hardware development project risks that are due to uncertainty factors. The presented methodological approach to quantitative risk assessment is a synthesis of mathematical uncertainty modeling and simulation modeling, the former being constructed on the basis of the fuzzy set theory, the possibility theory, and time series forecasting methods.

This part of the paper (Part I) presents a general theory for quantitative assessment of space hardware development project risks and theoretical basics for retrospective source data uncertainty modeling by counterpart products.

A practical implementation of the presented results will make it possible to significantly improve the quality of the feasibility study of new home space hardware development projects.

Keywords quantitative risk assessment, mathematical uncertainty modeling, simulation modeling method, methods and algorithms, space hardware, uncertainty factors.

1. Briukhovetskaia N. E., Pedersen I. A. Study of the nature of an innovation risk and approaches to its assessment (in Russian). Mekhanizm Rehuliuvannia Ekonimiky. 2011. No. 3. Pp. 64-70.

2. Bykov A. A. On problems in the development of risk assessment methods (in Russian). Problemy Analiza Riskov. 2008. V. 5, No. 2. Pp. 4-7.

3. Bykov A. A., Porfiriev B. N. On risk analysis, concepts, and classification (in Russian). Problemy Analiza Riskov. 2006. No. 4. Pp. 319-337.

4. Lavrinov G. A., Podolsky A. G. Content of the notions of uncertainty and risk in the preparation and implementation of weapon and military equipment development plans (in Russian). Vooruzhebiye i Ekonomika. 2010. No. 1 (9). Pp. 53-59.

5. Lutay A. N. Risk assessment for a project on the development of a new aeronautical product using a case-based approach (in Russian). Aviatsionno-Kosmicheskaya Tekhnika i Tekhnologiya. 2010. No. 5 (72). Pp. 105-112.

6. Latkin M. A., IlyushkoV. M. Project duration and cost assessment with account for the adverse effect of risks (in Russian). Aviatsionno-Kosmicheskaya Tekhnika i Tekhnologiya. 2008. No.3 (50). Pp.. 94-98.

7. Spitsin A. G., Lavrinov A. G., Khmelevoy V. V. Risk analysis in aeronautical hardware design (in Russian). Vooruzheniye i Ekonomika. 2011. No. 3 (15). Pp. 35-44.

8. Preliminary design of the "Sich-2M Spacecraft" development project, Explanatory report. Part 11. Technoeconomic indices of the making of the spacecraft and the ground-based equipment (in Russian). / Yuzhnoye State Design Office - 2017. (Office Number 311/1096 of March 2, 2017).

9. Pylypenko O. V., Pereverzev E. S., Alpatov A. P., Marchenko V.T.,Pechenevskaia O. K., Khorolskii P. P. Efficiency of Scientific and Technical Projects and Programs (in Russian). Dnipropetrovsk: Porogi, 2008. 509 pp.

10. Marchenko V. T., Petlyak E. P., Sazina N. P., Khorolsky P. P. New method of engineering evaluation of spacecraft for Earth remote sensing (in Russian). Technical Mechanics. 2017. No.2. Pp. 41-50.

11. Vartanyan V. M., Revenko D. S., Lyba V. A. Uncertainty in economic processes: emergence factors and description methods (in Russian).. Ekonomika ta Upravlinnia Pidpryiemstvamy Mashynobudivnoi Haluzi: Problemy Teorii ta Praktyky. 2009. No. 2 (6). Pp. 4-12.

12. Alpatov A. P., Marchenko V. T., Sazina N. P., Khorolsky P. P. Methodological approach to technical and economic feasibility of projects for new space technology products (in Russian). Tekhnicheskaya Mekhanika. 2015. No. 3. Pp. 3-17.

13. Alpatov A. P., Marchenko V. T., Khorolskyi P. P., Sazina N. P Methodological aspects of the financial and economic justification of conceptual problems in the space industry (in Ukrainian).. Kosmichna Nauka $\mathrm{i}$ Tehnologia. 2014. V. 20, No. 6 (91). Pp. 49-59.

14. Turko D. A. Accounting for uncertainty and risk conditions in the process of decision making in scienceintensive high-technology production (in Russian). Otkrytye Informarmatsionnye i Kompyurernye Tekhnologii. 2009. No. 43. Pp. 180-187.

15. Emelyanov A. A., Vlasova E. A., Duma R. V. Simulation Modeling of Economic Processes (in Russian): manual. Moscow: Finansy i Statistika, 2002. 368 pp. 
16.Khakhulin G. F. Basics of Simulation Model Construction (in Russian): manual. Moscow.: NTK Potok, 2002. $222 \mathrm{pp}$.

17. Smolyak S. A. Investment Project Efficiency Assessment in Risk and Uncertainty Conditions. Expected Benefit Theory (in Russian). Central Economic Mathematical Institute of the Russian Academy of Sciences. Moscow: Nauka, 2002. $181 \mathrm{pp}$.

18. Savilov S. I. Problems in accounting for integral uncertainty in investment project efficiency assessment in the nonstationary Russian economy (in Russian). Natsionalnye Interesy: Prioritety i Bezopasnost. 2015. No. 30. Pp.48-47.

19. Zak Yu. A. Decision Making under Fuzzy Conditions: Fuzzy-Technologies (in Russian). Moscow: Knizhny Dom LIBROKOM, 2013. 352 pp.

20. Shtovba S. D. Introduction to Fuzzy Set Theory and Fuzzy Logic (in Russian). URL: http://matlab.exponenta.ru/ fuzzylogic/index.php.

21. Dubois D., Prade H. Possibility Theory. Applications to Knowledge Representation in Computer Science (in Russian). Translated from French. Moscow: Radio i Svyaz, 1990. 288 pp.

22. Pytyev Yu. P. Possibility Theory Elements and Applications (in Russian). Moscow: Editorial URSS, 2000. $192 \mathrm{pp}$.

23. Pytyev Yu. P. On stochastic possibility modules (in Russian). Intellektualnye Sistemy. 2001. V. 6, Issue. 1-4. Pp. 25-62.

24. LarichevV. N. Decision Making Theory and Methods (in Russian). Moscow: Logos, 2000. 296 pp.

25. Gritsyuk S. N., Mirzoeva E. V., Lysenko V. V. Mathematical Methods and Models in Economics (in Russian): manual. Rostov-on-Don: Feniks, 2007. 348 pp.

26. Marchenko V. T., Syutkina-Doronina S. V., Sazina N.P. On the method of simulation of uncertainties of technical and economical data for problems of evaluation of research projects (in Russian). Tekhnicheskaya Mekhanika. 2016. No. 2. Pp. 137-146. 